\title{
Exploring Economics Teachers Perceptions of the Training-of-Teachers Project as an Professional Development Strategy
}

\author{
Micheal M van Wyk \\ Department of Curriculum and Instructional Studies, \\ School of Teacher Education, College of Education, \\ University of South Africa, Pretoria \\ vwykmm@unisa.ac.za
}

Doi:10.5901/mjss.2014.v5n1p753

\begin{abstract}
South Africa is going through several education reforms in order to prepare more learners for challenges and success in the $21 s t$ century and beyond. A key to the success of the reforms is the quality of teachers and their teaching methods. A profound change in teacher practices is called for, which would entail theestablishment of sustainable enabling teachingand learning environments and conditions which promote fundamental and critical engagement ina transformative education system. In view of the latter, the primary objective of this paper is to investigate economics teachers' perceptions of the Training-of-Teachers initiative (TOT) as a professional development strategy in Free State secondary schools. To achieve this objective, the following research questions are formulated: What is economics education and why is it important to promote this phenomenon in South African schools? and What constitutes the Training-of-Teacherss project as ptofessional development strategy Free State secondary schools? An exploratory, descriptive, contextual quantitative research approach was selected. A pretestposttest design was constructed, making use of EMT data collection instrument. A sample of two hundred and sixty seven economics teachers $(n=267)$ were selected to participate in the research study. The results of this study indicate that there were significant differences between the female group as compared to the male group as regards the pretest-posttest scores. Teachers exposed to the ToT initiative performed better in economic literacy, positive attitude toward economics and experienced an increase in understanding economics as a discipline. Finally, the ToT initiative impacted significantly on teachers' learning in economics education.
\end{abstract}

Keywords: Curriculum and Assessment Policy Statement, Training-of-Teachers initiative, economics teachers, pretest-posttest design

\section{Introduction}

South Africa is going through several education reforms in the last decade in order to prepare and educate school leavers for the global challenges and success in the 21st century and beyond. A key to the success of these reforms is the efficiency and competence of the quality of teachers and their teaching methods as stake to economic development. The Curriculum and Assessment Policy Statement (CAPS) curriculum policy emphasizes a problem-based approach, and requires teachers to make a praxis paradigm shift in employing active and participative teaching methods (Department of Basic Education (DBoE) 2010). As an all-embracing policy framework, this applies also to the subject of economics. The CAPS curriculum framework establishes that learners should be encouraged to gather relevant information and to transform such information into marketable knowledge.Several research studies informed us that most teachers tend to rely on the traditional forms of teaching practices. It is therefore to note that the success of these curriculum reforms depends in part on changing why and how South African teachers execute their pedagogical roles in the classroom. Research in South African schools has shown that unless teachers realize the need for a new approach to teaching and challenge their traditional views of the nature of learning and teaching, real change is unlikely to occur (van Wyk, 2012; Gao 1992; Gao et al., 1989). According to Van Wyk, (2012) "Changing the conceptions of teaching and schooling is now the key to improving students' quality" (p. 9). The author further posits that changing how teachers conceive of teaching appears to be urgent in the current South African educational landscape. However, first it is important to understand teachers' current conceptions of effective teaching for excellence. The question of what constitutes effective teaching has been researched for decades. However, changes in classroom praxis, assessment strategies, the availability of excellent and applicable resources could be catalyst for enhancing learner performances (Darling-Hammond and Bransford 2005). Moreover, Tschannen-Moran et al. (2001) is of the view that a better understanding of what constitutes good teacher practices must be investigate to support teachers daily. A profound 
change in teacher practices is called for, which would entail the establishment of sustainable enabling teachingand learning environments and conditions whichpromote fundamental and critical engagement ina transformative education system. It is recommended that professional teachers should be regarded as the essential resource of the education system, and that programmes for teacher education and training should reinforce the professional competencies and commitments of teachers, as stipulated in the Norms and Standards for Educators policy document (NDE 1997). In South Africa, this can be seen as a response to the government's call for a more socially responsive education system. Within this legislation, it is suggested that schools and universities in particular, should be more responsive to local and national needs when addressing socialproblems such as poverty, unemployment, crime, and the lack of health and associated facilities. Walstad and Rebeck (2001) mentioned that a viable education system with committed, competent and confident teachers is a primary condition for achieving quality education for all, especially within the new Curriculum and Assessment Policy Statement (CAPS) for South African schools.

In view of the challenges to the South African education landscape, the objective of this paper is to explore economics teachers' perceptions of the Training-of-Teachers (TOT) project as a driver for professional development in Free State secondary schools. To achieve this objective, the following research questions are formulated:

- What is economics education and why is it important to promote this phenomenon in secondary schools?

- What constitutes the Training-of-Teachers project and what are the main findings of this investigation in Free State seconday schools?

In the next paragraphs, economics education is conceptualized and the importance of this phenomenon is discussed. Secondly, the Training-of-Teachers initiative as a professional development strategy is discussed Furthermore, the results of the investigation are explained. Finally, conclusions were highlighted and recommendations formulated for further investigation into economics education as an important school subject.

\subsection{What is economics education?}

Economic education focuses on the scholarship of teaching and learning economics as a subject. It encompasses the content to be taught (what-subject content knowledge), different teaching methods (how-pedagogical content knowledge), designing of applicable assessmentpractices (why-purpose of using assessment tools/strategies), and information of general interest to teachers of economics in primary, secondary to undergraduate studies. The purpose of economic education is to create future responsible citizens, effective decision-makers and voters for change. Economic education is a very crucial subject that many of our nation's schools tend to overlook. The importance of economic education goes far beyond the goal of improving an understanding of the basic principles of supply and demand and the workings of the economy. Economics can be taught by generating new knowledge with the help of exposing students to real-life learning environments and experiences. Students develop perceptions of their economic world at an early age, which, as they progress through the educational process, develop into attitudes and opinions about the subject of economics. Intended or not, teachers influence the direction of attitude development. My view is that we must equipped our learners with effective money management skills and provide an understanding of how our ever-changing, fast-paced global economy works to avoid future global economic crisis. Walstad and Rebeck (2001) concurred and argues that economic knowledge is vital important for economic growth and development. The importance of economics education goes far beyond the goal of improving an understanding of the basic principles of supply and demand and the workings of our economy. Learners develop perceptions of their economic world at an early age, which, as they progress through the educational process, develop into attitudes and opinions about the subject of economics. Intended or not, teachers influence the direction of attitude development (Shiller 2010; Walstad, 1992, 1997).

\subsection{Why the importance of economics education?}

The global economy has changed many of the ways we live and do business. It is critical that we equip our learners and students, the workforce of tomorrow, with an understanding of how the economy works, and knowing how it affects everything from money management to small business to large corporations. A foundation in economic and financial literacy will inspire entrepreneurship, innovation, and prepare students to successfully adapt to a dynamic marketplace.By finding ways to teach learners more about economics, teachers are contributing to improved attitudes toward the subject. By teaching basic economic concepts and applying them to classroom discussions of economic issues and institutions, teachers are not indoctrinating learners, but providing a knowledge foundation for more informed learner opinions and decision making on vital issues. The more economics concepts learners know, the more they like 
and value the subject and the more information they have about economic issues. Learners who do not get the opportunity to learn economics and increase their economic understanding will probably never take much interest in the subject or in their economic world. Economic education is extremely important because it is vital to the future health of our nation's economy. But why is economic education needed? Why can we not rely on the truths of economics being recognized by the intelligent public without deliberate, organized effort at public enlightenment? Economic education, aiming to enlighten the intelligent lay public to these significant—but still counter-intuitive-implications of economics, surely has a valuable role to play (Shiller 2010). Let us however now turn to the second of the reasons we have identified (as responsible for the need for economic education). Economic understanding does not call for sophisticated technical prowess. It does, however, require appreciation for a way of looking at human actions and of social interaction, which many at first find rather strange and unfamiliar. Economic understanding requires one to see the "objects" with which economic activity is concerned-the money, the natural resources, the capital equipment, the flows of half-finished goods, the fully produced goods ready for delivery to the consumer-from a subtly different perspective from that to which the layperson has been accustomed.

\subsection{Training-of-Teachers initiative as professional development strategy}

In the last decade guidelines covering subjects taught in South African schools were replaced by a single Curriculum and Assessment Policy Statement (CAPS) curriculum policy. The CAPS policy emphasizes a problem-based approach. This approach compelled teachers to make a praxis paradigm shift in employing active and participative teaching methods (Department of Basic Education (DBoE) 2010). As an all-embracing policy framework, this applies also to the subject of economics.The CAPS curriculum framework establishes that learners should be encouraged to gather relevant information and to transform such information into marketable knowledge. Again, this is also a specifically requirement of the CAPS curriculum policy for economics. The Training-of-Teachers initiative is a driver for teacher empowerment to deliver and employ effective teaching strategies to advance the subject in Free State FET schools. To achieve this purpose, it is vital to skill, educate and empower teachers in subject content knowledge (SCK) and pedagogical content knowledge (PCK) to create enabling learning environments for learners. Teachers of economics are therefore required to consider effective teaching approaches, strategies and methods in order to ensure that these objectives are achieved. By employing new approaches, strategies and methods, economics teachers can provide effective enabling teaching and learning environments in such a way as to ensure that knowledge, skills and positive attitudes are optimised among learners in their response to the socio-economic environment. The facilitation team incorporated content and pedagogyin the workshops through different learning activities in order to assist the facilitators' classroom practice, as well as to help teachers share and organize their ideas (knowledge) with fellow peers. The workshops were hosted in the educational districts centres of Free State Department of Basic Education. Each of the five centres administered a fourteen-day workshop for 267 subject teachers, which were conducted by faculty membersand alumni during June and September school holidays (2010-2012). Two hundred and sixty seveneconomics teachers participated in the workshops. Eligibility was limited to secondary-school-level teachers who would be teaching an economics class. Contrary to normal practice, however, the centres oversubscribed eligible applicants in order to secure enough teachers to populate the workshops. Each workshop consisted of fourteen days of training and lesson demonstrations using an economics curriculum manual. The workshop topics included standard treatments of introductory market economics, microeconomics, macroeconomics, international trade (globalization) and contemporary economics issues (DoE 2011). Teachers working on the same topic formed expert groups consisting of four to five teachers per group. During this phase, teachers shared their concept maps and discussed the main ideas of the topic with other "experts", and then refined their own concept maps. The purpose of this phase was to facilitate teachers' development of "expert knowledge" before proceeding to the next phase of the class sessions into groups. These manuals were compiled in accordance with unit for each session per day. Facilitators used an instructional video to present the concepts on Contemporary Economic Issuesas a unit in the manual. In this unit, activities included individual study and group presentations. Groups watch the role-playing video with a worksheet and later meet to discussion and to plan for their specific group presentation on a specific topic e.g poverty or unemployment. Teachers were also provided with worksheets to guide their observations and to record their results.

\section{Research Methodology}

An exploratory, descriptive and quantitative research approach was selected for the purpose of conducting this study. A pretest-posttest design was constructed, making use of three data collection instruments (Cohen et al. (2009). A sample 
of two hundred and sixty seven economics teachers $(n=267)$ in the FSDoE was selected to participate in the research study. Data was collected by using the research instrument, the Economics Modular Test (EMT), which covered all six units of the seminars of the ToT project. The EMT content topics were macroeconomics, microeconomics, contemporary economic issues and globalization. The reliability of an instrument indicates the accuracy with which the sample represents the accuracy of the broader universe of responses (Cohen Mansion and Morrison 2009). Consent was obtained from the FSDoE, school principals and FET economics teachers before the study was begun. An official FSDoE letter explaining the purpose of the study was attached to the questionnaire. The letter also highlighted the confidentiality of any results deriving from each teacher's participation. Each participant signed a consent letter.

\section{Results and Discussion}

\subsection{EMT test performance scores on teacher learning}

Test performance compared the learning performance outcomes of the two groups [gender] by analysing the scores achieved in the EMT completed by the teachers during the last lesson unit. In all the training units, facilitators first showed teachers an instructional digital video on the basic economic concepts of modular units [demonstration of economic lessons].

Table 1: Gender Pretest-Posttest scores on four topics

\begin{tabular}{|l|c|c|c|c|c|c|}
\hline Topics cover during ToT project & $\mathrm{N}$ & $\begin{array}{c}\text { Cronbach alpha } \\
\mathrm{a}=.7\end{array}$ & Male & Female & $\mathrm{t}$ & Sig. (2-tailed) \\
\hline Macroeconomics & 267 & .891 & 70.5 & 68.8 & $3.24^{\star \star}$ & $0.000^{\star}$ \\
\hline Microeconomics & 267 & .794 & 77.1 & 86.9 & $2.09^{*}$ & $0.003^{* *}$ \\
\hline Contemporary economic issues & 267 & .811 & 77.5 & 78.8 & $3.64^{* \star}$ & $0.000^{*}$ \\
\hline Globalization & 267 & .801 & 68.5 & 79.8 & $2.54^{\star \star}$ & $0.000^{*}$ \\
\hline
\end{tabular}

${ }^{*}$ Test $=100$ scoring; ${ }^{\star} p<0.05 ;{ }^{* \star} p<0.01 ; a=0.7 .0$

Table 2 shows a summary of the results of male and female teachers' performance in the four topics tests. All topics met the Cronbach alpha reliability test $(\alpha=0.7)$. Results indicated that there were significant differences between the pretestposttest scores of all teachers who attended the ToT project. Female participants outperform male participants on the topics Contemporary Economics Issues (78.8\%), Globalization (79.8\%) and Microeconomics (86.9\%). Overall the all teachers show an increase all the tests of the topics.

Table 2: Pretest-Posttest scores on four topics

\begin{tabular}{|l|c|c|c|c|c|c|c|}
\hline & & & Pretest & Posttest & \multicolumn{3}{|c|}{ Outcome } \\
\hline Topics cover during ToT project & $\mathrm{N}$ & $\begin{array}{c}\text { Cronbach alpha } \\
\mathrm{\alpha}=.7\end{array}$ & & & \% Change & $\mathrm{T}$ & Sig. (2-tailed) \\
\hline Macroeconomics & 267 & .891 & 59.5 & 68.8 & 13.5 & $3.24^{\star \star}$ & $0.000^{\star}$ \\
\hline Microeconomics & 267 & .794 & 57.1 & 66.9 & 14.6 & $2.09^{\star}$ & $0.003^{\star \star}$ \\
\hline Contemporary economic issues & 267 & .811 & 57.5 & 73.8 & 22.0 & $3.64^{\star \star}$ & $0.000^{\star}$ \\
\hline Globalization & 267 & .801 & 52.5 & 60.8 & 13.7 & $2.54^{\star \star}$ & $0.000^{\star}$ \\
\hline
\end{tabular}

${ }^{*}$ Test= 100 scoring; ${ }^{*} \mathrm{p}<0.05 ;{ }^{* *} \mathrm{p}<0.01 ; \alpha=0.7 .0$

Table 2 shows a summary of the results of teachers' performance in the four topics tests. All topics met the Cronbach alpha reliability test $(\alpha=0.7)$. Results indicated that there were significant differences between the pretest-posttest scores of all teachers who attended the ToT project. The topic, Contemporary Economics Issues achieved higher score as shown in the Table 2. The results are as follows: Contemporary Economics Issues, Macroeconomics, Microeconomics and Globalization, $t(267) 3.64, P<0.01 ; 3.24, P<0.01 \& P<0.05$. Overall the

\subsection{Economics teachers' interactions during group discussions}

Questions 5-7 were asked regarding group discussions of topics in the groups. Table 3 compares male and female group 
interactions as regards behaviour amongst the participants and the facilitators. Several research studies conducted on the learner centredness approach have shown that interactions may take place in a variety of ways, such as exchanging resources, providing or seeking information on the project, giving and receiving feedback and encouraging group members (van Wyk 2012; Tschannen-Moran et al. 2001). To examine the interactions among teachers, the researcher has studied digital recordings of group discussions that took place during groups research project topics. The results are analyzed below.

Table 3: Male and Female interactions during discussion groups $(n=267)$

\begin{tabular}{|c|l|c|c|c|c|c|}
\hline Question & Group behavior & Gender & $f$ & $\%$ & Mean & $t$-value \\
\hline \multirow{2}{*}{5} & \multirow{2}{*}{ Exchanging information } & Male & 144 & 53.9 & 3.5 & $3.14^{\star \star}$ \\
\cline { 3 - 8 } & & Female & 123 & 46.1 & 3.2 & \\
\hline \multirow{2}{*}{6} & \multirow{2}{*}{ Receiving feedback /Support from facilitator } & Male & 116 & 43.4 & 2.1 & $2.06^{\star}$ \\
\cline { 3 - 8 } & & Female & 151 & 56.6 & 3.3 & \\
\hline \multirow{2}{*}{7} & \multirow{2}{*}{ Encouraging group members } & Male & 120 & 44.5 & 3.3 & $2.09^{\star}$ \\
\cline { 3 - 8 } & & Female & 147 & 55.0 & 3.6 & \\
\hline
\end{tabular}

${ }^{*} p<0.05 ;{ }^{* \star} p<0.01$ Scale: $S A=$ Strongly agree, A=Agree, $D=$ Disagree, SD=Strongly disagree

The percentage figures in Table 3 were calculated by dividing the frequency of interaction by the total number of units of analysis in each group's behaviour and how it was observed per group. With both groups, these results showed that exchanging information was the most noticeable interactive behaviour. Data reflected that the male group exchanged more information during group discussions (male group $=53.9 \%$ vs female group $=46.1 \%$ ). As regards the data in Question 7, the female group demonstrated twice as much interaction per group activity (56.6\% vs $43.4 \%$ ) than the male group. The female group also a better score in Question 6, which reflected the degree to which they received feedback and support from facilitator (55.0\% vs $44.5 \%)$. Results indicated that there were significant differences of teachers who attended the ToT project.

\subsection{Teachers perceived interactions in the group learning activities}

Table 4 summarises the results of teachers' perceptions on the quality of interactions among participants during the learning activities.

Table 4: Teachers perceived interactions in the group learning activities $(n=267)$

\begin{tabular}{|c|l|c|c|c|c|c|}
\hline \multirow{2}{*}{ Question statement } & Gender & $\begin{array}{c}\text { SA \& A } \\
(\%)\end{array}$ & $\begin{array}{c}\text { D \& SD } \\
(\%)\end{array}$ & Mean & $\begin{array}{c}\text { t- } \\
\text { value }\end{array}$ \\
\hline \multirow{2}{*}{8} & \multirow{2}{*}{ I/We had good interactions with other members in our group } & Male & 87 & 13 & 3.9 & $3.67^{\star \star}$ \\
\cline { 3 - 8 } & & Female & 89 & 11 & 3.0 & \\
\hline \multirow{2}{*}{9} & \multirow{2}{*}{ I/We had good interactions with the facilitator in our group } & Male & 81 & 19 & 3.6 & $2.79^{\star \star}$ \\
\cline { 3 - 8 } & & Female & 88 & 12 & 2.4 & \\
\hline \multirow{2}{*}{10} & I/We like to work together with my/our group members using & Male & 88 & 12 & 3.6 & $2.77^{\star \star}$ \\
\cline { 3 - 8 } & economics concepts & Female & 84 & 16 & 3.0 & \\
\hline \multirow{2}{*}{11} & $\begin{array}{l}\text { I/We built good relationships and could depend on each other } \\
\text { to succeed in our group activities }\end{array}$ & Male & 90 & 10 & 3.7 & $2.10^{\star}$ \\
\cline { 3 - 8 } & Female & 87 & 23 & 2.9 & \\
\hline
\end{tabular}

${ }^{*} p<0.05$; ${ }^{*} \mathrm{p}<0.01$ Scale: $\mathrm{SA}=$ Strongly agree, A=Agree, $\mathrm{D}=$ Disagree, SD=Strongly disagree

Table 4 presents data regarding teachers' perceived interactions with each other while participating in economics activities. The female group perceived better group interactions with their peers during group learning (Question 8, $\mathrm{t}(267)=3.67, \mathrm{P}<0.01$; Question 9, $\mathrm{t}(267=2.79, \mathrm{P}<0.01$ and Question 10, $\mathrm{t}(267)=2.77, \mathrm{P}=0.01)$ as compared to the normal group. Ninety-seven percent of the expert group agreed that they had good interactions with other members in their groups, as well with facilitators (81\%). They also said that they liked working with their group members (88\%) using economics concepts (Question 8 and 9, SA \& A). Teachers in the group exchanged ideas and engaged in interactions with their group members more consistently as compared to the female group. In Question $11, t(267) 2.1, P=0.05$, the male group indicated that they had built good relationships and could depend on each other to succeed in their group 
activities (90\%) in the group learning activities.

\section{Discussion of Results}

The results of this study indicate that there were significant differences between the female and male participants on the pretest-posttest scores of data collection instrument. This suggests that teachers exposed to the ToT initiative performed better in economic literacy, positive attitude toward economics and experienced an increase in understanding economics as a discipline. We can therefore conclude that the ToT initiative impacted significantly on teachers' learning in economics education. Van Wyk (2012) conducted a similar study which concurred with the findings of this study that showed the ToT initiative is an effective, powerful and applicable empowerment project to advance economics education in FSDoE schools.

The results of this study are consistent with student reactions to cooperative learning groups discussed by other researchers (Tschannen-Moran et al. 2001; Vaughan 2002). Previous studies conducted indicated that students in the cooperative learning group showed greater academic achievements and knowledge retention than those in the control group (Tran and Lewis 2012; Van Wyk 2010; Ghaith \& Shaaban 1999). In the present study, the teachers in the expert group reported more effective learning in groups, more helpfulness and mutual teaching, more discussion of the learning material among participants and a greater level of information exchange than they had experienced in traditional teachercentered classrooms.

Research has shown that interactions during male and female groups work may occur in a variety of ways, such as exchanging resources/information, giving/receiving help/feedback, and challenging and encouraging other students (Tschannen-Moran et al. 2001; Van Wyk 2012). During this study it was observed that teachers always exchanged concept ideas in mind maps with team members when participating in the selected expert group. It was also observed that participants really supported and exchanged each other's ideas regarding the structuring of different mind maps.

The present study appears to support Dickie (2006) findings that achievement and attitudes in the cooperative learning context are strongly correlated. Specifically, this ToT initiative spur teachers to greater levels of achievement, which in turn had a positive impact on their attitudes to teaching. The results of this study concur with previous studies that show that teachers' ability to share their work instantaneously with other teachers in the expert group is motivating because it allows them to receive almost instant feedback on their work (van Wyk 2012; Coladarci 1992,).

\section{Concluding Remarks}

Results indicated that there are significant differences between the pretest-posttest scores of the female group as compared to the male group. This implies that teachers exposed to the ToT project performed better in the all the posttest scores. Research has shown that interactions during male and female groups work may occur in a variety of ways, such as exchanging resources/information, giving/receiving help/feedback, and challenging and encouraging other students. Results indicated that there were significant differences of teachers who attended the ToT project as driver for teacher professional development strategy.

\section{Further Research, Limitations and Recommendations}

The findings of the present study indicate the positive effects of Training-of-Trainers project on economics teachers' views toward their own learning, as well as towards the subject. However, it is difficult to demonstrate a generalisable effect on teacher attitudes from a short period of training, such as that reported in this research study. In addition, attitudes are both abstract and subjective, and it is therefore difficult to measure changes in attitude over a short time. The following recommendations are formulated to advance economics education in South Africa beyond the $21^{\text {st }}$ century;

o Coordinate teacher workshops, co-presented by professional teachers and economists in all nine provincial departments of education;

o Develop after-school activities, such as the development of entrepreneurial skills;

o Researching on economics education in South African schools to advance the quality of teaching and learning of the subject; and

o Plan and establish virtual centres of economics education at higher education institutions.

Further research need to be conducted because of limitations. One must view the present study cautiously because of four limitations. The first limitation concerns the sample size which involved a small number of ToT teachers 
( $n=267)$ who participated in this study.Because of the restricted range of participants,in future research studies, the researcher should include a more diverse and representative sample ofteachers and learners. The second limitation is the time factor. This study was conducted only on a fourteen day workshop. A longer investigation period will maybe yield different results. The third limitation is economics subject knowledge andpedagogical knowledge. This was a serious concern for some teachers because of limited orlack of knowledge regarding pre-course economics content and different teaching strategies. This impeded a lot on how to learn the subject and how to implement applicable teaching strategies to enhance their praxis.

\section{Acknowledgement}

I am indebted to the critical reviewer for constructive feedback on this paper. Acknowledgements are due to the Trainingof-Teachers facilitators, economics teachers, language editing coordinator and the research assistant, who voluntarily participated in this research study as part of this inaugural lecture. I also acknowledge the financial contributions made by the National Research Foundation of South Africa (NRF) for the grant funding (ID.76348) Ref No: TK 2008043000005. Any opinions, findings, and conclusions expressed in this lecture are those of the author and do not reflect the views of the NRF or the Department of Curriculum and Instructional Studies, College of Education.

\section{References}

Cohen L, Manion L, Morrison K 2009. Research methods in education. $6^{\text {th }}$ Edition.London: Routledge Farmer.

Coladarci T 1992. Teachers' sense of efficacy and commitment to teaching. Journal of Experimental Education, 60(4): 323-337.

Darling-Hammond, L., \& Bransford, J. (2005). (Eds.). Preparing teachers for a changing world: What teachers should learn and be able to do. San Francisco: Jossey-Bass.

Department of Basic Education (DBoE). 2010. Curriculum and Assessment Policy Statement (CAPS) Department of Basic Education. Government Press: Pretoria.

Dickie M 2006.Do classroom experiments increase learning in introductory microeconomics? Journal of Economic Education, 37: 267288.

Ghaith G, Shaaban K 1999. The relationship between perceptions of teaching concerns, teacher efficacy, and selected teacher characteristics. Teaching and Teacher Education, 15: 487-496.

Goddard RD, Hoy, WK, Woolfolk WK, Hoy A 2000. Collective teacher efficacy: Its meaning, measure, and impact on student achievement. American Educational Research Journal, 37: 479-507.

Ghaith G, Yaghi H 1997. Relationships among experience, teacher efficacy, and attitudes toward the implementation of instructional innovation. Teaching and Teacher Education, 13: 451-458.

Gao, L. (1992). The generative style of teaching: Rationale and practice. Paper presented at the meeting of the ICTPE, Dortmund, Germany.

Gao, L., Adcock, H., Carr, M., Hume, A., Nicholson, D., Silvester, J., et al. (1989). An account of action research investigating teacher change. Research in Science Education, 19(1), 112e122. doi:10.1007/BF02356851.

Gao, L., \& Watkins, D. A. (2002). Conceptions of teaching held by school science teachers in P.R. China: identification and crosscultural comparisons. Science Education, 24(1), 61e79. doi:10.1080/09500690110066926.

National Department of Education. 1997. Norms and Standards for Educators policy document Pretoria: Government Press

National Council on Economics Education 2005. Train the Trainers Programme 2005-2007: Seminars A,B, C and D. Economics International. New York.

National Policy Framework for Teacher Education and Development in South Africa (National Department of Education 2007),

National Department of Education 2003. National Strategy for Further Education and Training: Policy. Pretoria: Government Press.

Shiller RJ. 2010. How Should the Financial Crisis Change How We Teach Economics? The Journal of Economic Education, 41(4): 403409. http://dx.doi.org/10.1080/00220485.2010.510409 (Retrieved 12 March 2013)

Soodak LC, Podell DM 1994. Efficacy and experience: Perceptions of efficacy among pre-service and practicing teachers. Journal of Research and Development in Education, 30(4): 214-221.

Tschannen-Moran M, Woolfolk Hoy A 2001. Teacher efficacy: Capturing and elusive construct. Teaching and Teacher Education, 17: 783-805.

Vaughan W 2002. Effects of Cooperative Learning on Achievement and Attitude Among Students of Color.The Journal of Educational Research. 95(6): 359-364.

Van Wyk MM 2012. Effectiveness of the Training of Teachers project in Economics education in Free State secondary schools. Journal of Social Science, 30(3):243-250

Van Wyk, MM and G Alexander. 2010. Do Teaching Methods Presented by the National Council on Economics Education (USA) Enhance Trainers' Learning Capacity in Economics Education? A South African Perspective.Journal of Social Science, 23(3): 159-169

Van Wyk MM, Alexander G \& Moreeng BB. 2010. Education as Transformation: A case of a Faculty. South African Journal for Higher 
Education, 24(6): 1036-1051

Van Wyk MM 2007. The Use of Cooperative Learning in the Further Education and Training Phase in the Free State Province. Ph.D. Thesis, Unpublished. Bloemfontein: University of the Free State.

Walstad WB 1997. "Effectiveness of a USMES In-Service Economics education Program for Elementary School Teachers," Journal of Economics education, 11(1):1-12.

Walstad WB 1992. Economics instruction in high schools. Journal of Economic Literature, 30(2):19-51.

Walstad WB, Rebeck K 2001.Teacher and student economic understanding in transition economies. Journal of Economic Education, 3(2): 57-67)

Wheatley KF 2005. The case for reconceptualising teacher efficacy research. Teaching and Teacher Education, 21: 747-766. 